\title{
Efficacy of Fungicides for Control of Sclerotinia Stem Rot of Canola
}

C. A. Bradley and H. A. Lamey, Department of Plant Pathology, North Dakota State University, Fargo 58105; G. J. Endres and R. A. Henson, Carrington Research Extension Center, North Dakota State University, Carrington, 58421; B. K. Hanson, Langdon Research Extension Center, North Dakota State University, Langdon 58249; K. R. McKay and M. Halvorson, North Central Research Extension Center, North Dakota State University, Minot 58701; and D. G. LeGare and P. M. Porter, Department of Agronomy and Plant Genetics, University of Minnesota, St. Paul 55108

\begin{abstract}
Bradley, C. A., Lamey, H. A., Endres, G. J., Henson, R. A., Hanson, B. K., McKay, K. R., Halvorson, M., LeGare, D. G., and Porter, P. M. 2006. Efficacy of fungicides for control of Sclerotinia stem rot of canola. Plant Dis. 90:1129-1134.

Sclerotinia stem rot (SSR), incited by Sclerotinia sclerotiorum, causes yield reductions to canola (Brassica napus) grown in North Dakota and Minnesota. Field trials were conducted in North Dakota and Minnesota from 2000 to 2004 to evaluate the effect of foliar fungicides on SSR and canola yield. Levels of SSR varied among years and location. In general, fungicides that consistently reduced SSR incidence compared with an untreated control were azoxystrobin, benomyl, boscalid, iprodione, prothioconazole, tebuconazole, thiophanate-methyl, trifloxystrobin, and vinclozolin. Significant reductions in SSR incidence with fungicides did not always translate into differences in canola yield, however. Inconsistent results were observed with different timings of applications based on percent bloom. This indicates that application timing should be based on factors in addition to percent bloom.
\end{abstract}

Additional keywords: Benlate, Blocker, Endura, Folicur, Gem, JAU6476, Omega, Quadris, rapeseed, Ronilan, Rovral, Topsin M, white mold

Sclerotinia stem rot (SSR), caused by Sclerotinia sclerotiorum (Lib.) de Bary, is a major disease of canola (rapeseed, Brassica napus L.) grown in North Dakota and Minnesota. SSR incidence has ranged from 7 to $19 \%$ in North Dakota from 1991 to $2002(4,5)$ and 11 to $19 \%$ in Minnesota from 1996 to 2002 (4).

Because no commercial canola cultivars currently have complete resistance to $S$. sclerotiorum (1), use of fungicides is the primary method of controlling SSR. Historically, benomyl fungicide (trade name: Benlate; DuPont Agricultural Products, Wilmington, DE) had been used effectively for controlling SSR in canola in Canada $(2,11)$, and was in the process of becoming registered on canola in the United States; however, DuPont terminated manufacturing and sale of Benlate in 2001. Other fungicides such as iprodione and vinclozolin also have been used for SSR control in Canada $(2,11)$, and newly registered and experimental fungicides have the potential for providing excellent control of SSR. Although canola growers in Minne-

Corresponding author: C. A. Bradley

E-mail: carl.bradley@ndsu.edu

Accepted for publication 1 May 2006.

DOI: 10.1094/PD-90-1129

(C) 2006 The American Phytopathological Society sota and North Dakota have access to a Sclerotinia risk forecasting system (6) which helps with fungicide application decisions, it does not provide help in choosing which fungicide to apply. Canola growers in North Dakota currently have four fungicide active ingredients registered for control of SSR on canola (azoxystrobin, boscalid, thiophanate-methyl, and vinclozolin; 7). If a fungicide application is warranted, the use of the most effective economical fungicide product will give growers the greatest return on their investment. The objective of this research was to evaluate the efficacy of several fungicides for control of SSR of canola.

\section{MATERIALS AND METHODS}

In all, 16 field environments which consisted of several locations and years between 2000 and 2004, were used to evaluate the efficacy of several fungicides on SSR, (Table 1). Trials that were located on commercial fields relied on natural rainfall and disease pressure, whereas trials located on research farms were mist irrigated and relied on both natural disease pressure and augmented inoculum ( $S$. sclerotiorum ascospores provided by M. Boosalis, University of Nebraska, Lincoln). At each environment, an untreated control was included, but fungicide treatments varied by year and location and were azoxystrobin (trade name: Quadris; Syngenta Crop Protection, Greensboro, NC), benomyl (Benlate; DuPont Agricultural Products), boscalid (Endura; BASF Ag Products, Research Triangle Park, NC), fluazinam (Omega; Syngenta Crop Protection), iprodione (Rovral; Bayer CropScience, Research Triangle Park, NC), prothioconazole (JAU6476; Bayer CropScience), pentachloronitrobenzene (PCNB, Blocker; AMVAC Chemical Corp., Los Angeles), tebuconazole (Folicur; Bayer CropScience), trifloxystrobin (Gem; Bayer CropScience), thiophanate-methyl (Topsin M; Cerexagri, King of Prussia, PA), V10116 (Valent Agricultural Products, Walnut Creek, CA), and vinclozolin (Ronilan;

Table 1. Canola cultivar and irrigation information for each year and location

\begin{tabular}{llll}
\hline Year & \multicolumn{1}{c}{ Location $^{\text {a }}$} & \multicolumn{1}{c}{ Cultivar } & Mist irrigation used \\
\hline 2000 & Langdon, ND, REC & Pioneer 44A89 & Yes \\
2000 & Langdon, ND, commercial field & Golden Boy & No \\
2001 & Red Lake Falls, MN & Pioneer 44A89 & Yes \\
2001 & Langdon, ND, REC & Minot RR & Yes \\
2001 & Langdon, ND, commercial field & Minot RR & No \\
2001 & Carrington, ND, REC & Minot RR & Yes \\
2001 & Newburg, ND, commercial field 1 & Li-Bred 449 & No \\
2001 & Newburg, ND, commercial field 2 & Pioneer 45A55 & No \\
2002 & Langdon, ND, REC & LG 3455 & Yes \\
2003 & Langdon, ND, REC & Hyola 357 Magnum & Yes \\
2003 & Carrington, ND, REC & Hyola 357 Magnum & Yes \\
2003 & Minot, ND, REC & Invigor 2663 & Yes \\
2003 & Red Lake Falls, MN & Invigor 2663 & Yes \\
2004 & Langdon, ND, REC & Invigor 2663 & Yes \\
2004 & Carrington, ND, REC & Hyola 357 Magnum & Yes \\
2004 & Red Lake Falls, MN & Invigor 2663 & Yes \\
\hline
\end{tabular}

a $\mathrm{REC}=$ research extension center. 
BASF Ag Products). Fungicide applications were made with $\mathrm{CO}_{2}$-pressurized backpack sprayers calibrated to deliver between 131 and 188 liters/ha at 207 to $276 \mathrm{kPa}$ of pressure. Plot sizes varied with location and year and ranged from 1.5 to $1.8 \mathrm{~m}$ wide by 4.9 to $7.6 \mathrm{~m}$ long. Plots were arranged in a randomized complete block design with four replications.

Data from each location and year were analyzed separately due to differences in cultivars used and fungicide treatments tested. Data were statistically analyzed using the general linear model procedure (PROC GLM) in SAS (SAS Institute, Inc., Cary, NC). Fisher's protected least significant difference test was used to compare means, where $\alpha=0.05$.

\section{RESULTS}

2000. Significant differences among fungicide treatments were detected for SSR incidence and yield at the Langdon Research Extension Center (REC) in 2000 (Table 2). All fungicides except fluazinam significantly reduced SSR incidence compared with the untreated control. Most fungicide treatments provided a significant yield increase over the untreated control; however, fluazinam, trifloxystrobin, and vinclozolin at $420 \mathrm{~g}$ a.i./ha applied at 30 to $50 \%$ bloom did not.

Significant differences among fungicide treatments were detected for SSR incidence and yield at the commercial field in Langdon in 2000 (Table 2). All fungicide treatments significantly reduced SSR incidence compared with the untreated control.

Table 2. Effect of fungicides on Sclerotinia stem rot (SSR) incidence and canola yield at a field located on the research extension center (REC) and in a commercial field in Langdon, ND in 2000

\begin{tabular}{|c|c|c|c|c|c|c|}
\hline \multirow[b]{2}{*}{ Fungicide } & \multirow[b]{2}{*}{ Rate (g a.i./ha) } & \multirow[b]{2}{*}{ Timing ( $\%$ bloom) } & \multicolumn{2}{|c|}{ REC } & \multicolumn{2}{|c|}{ Commercial field ${ }^{a}$} \\
\hline & & & SSR incidence (\%) & Yield (kg/ha) & SSR incidence (\%) & Yield (kg/ha) \\
\hline Untreated & $\ldots$ & $\ldots$ & 17 & 2,322 & 27 & 2,424 \\
\hline Azoxystrobin & 175 & $10-20$ & 10 & 2,542 & 5 & 2,791 \\
\hline Azoxystrobin ${ }^{b}$ & 175 & $10-20$ & 10 & 2,578 & 3 & 2,673 \\
\hline Benomyl & 489 & $20-30$ & 2 & 2,714 & 2 & 2,677 \\
\hline Boscalid & 249 & $20-30$ & 6 & 2,622 & 1 & 2,571 \\
\hline Boscalid & 249 & $30-50$ & 3 & 2,791 & 7 & 2,743 \\
\hline Fluazinam & 248 & $10-20$ & 14 & 2,494 & 18 & 2,410 \\
\hline Fluazinam & 496 & $10-20$ & 14 & 2,341 & 8 & 2,553 \\
\hline Iprodione $^{c}$ & 504 & $20-30$ & 5 & 2,739 & 3 & 2,816 \\
\hline Tebuconazole & 126 & $20-30$ & 5 & 2,567 & 14 & 2,659 \\
\hline Tebuconazole & 190 & $20-30$ & 11 & 2,604 & 9 & 2,857 \\
\hline Trifloxystrobin & 175 & $10-20$ & 6 & 2,472 & 10 & 2,382 \\
\hline Trifloxystrobin & 245 & $10-20$ & 11 & 2,424 & 4 & 2,652 \\
\hline Vinclozolin & 375 & $30-50$ & 8 & 2,545 & 3 & 2,692 \\
\hline Vinclozolin & 420 & $30-50$ & 7 & 2,465 & 2 & 2,655 \\
\hline Vinclozolin & 420 & $20-30$ & 10 & 2,571 & NI & NI \\
\hline Vinclozolin & 420 & $50-60$ & 5 & 2,813 & NI & NI \\
\hline Vinclozolin ${ }^{\mathrm{b}}$ & 420 & $30-50$ & 5 & 2,663 & 1 & 2,857 \\
\hline LSD $0.05^{\mathrm{d}}$ & $\ldots$ & $\ldots$ & 5 & 210 & 5 & 303 \\
\hline
\end{tabular}

Table 3. Effect of fungicides on Sclerotinia stem rot (SSR) incidence and canola yield at a field located on the research extension center (REC) and in a commercial field in Langdon, ND in 2001

\begin{tabular}{|c|c|c|c|c|c|c|}
\hline \multirow[b]{2}{*}{ Fungicide } & \multirow[b]{2}{*}{ Rate (g a.i./ha) } & \multirow[b]{2}{*}{ Timing ( $\%$ bloom) } & \multicolumn{2}{|c|}{ REC } & \multicolumn{2}{|c|}{ Commercial field } \\
\hline & & & SSR incidence $(\%)$ & Yield (kg/ha) & SSR incidence (\%) & Yield (kg/ha) \\
\hline Untreated & $\ldots$ & & 59 & 1,433 & 12 & 2,004 \\
\hline Azoxystrobin & 175 & $10-20$ & 44 & 1,712 & 12 & 1,795 \\
\hline Benomyl & 561 & $30-40$ & 11 & 2,097 & 2 & 1,899 \\
\hline Boscalid & 200 & $30-40$ & 7 & 2,243 & 3 & 1,814 \\
\hline Boscalid & 249 & $10-20$ & 17 & 2,072 & 5 & 1,960 \\
\hline Boscalid & 249 & $30-40$ & 26 & 1,990 & 3 & 1,986 \\
\hline Boscalid & 249 & $50-60$ & 22 & 2,243 & 1 & 1,916 \\
\hline Boscalid & 299 & $30-40$ & 1 & 2,433 & 1 & 1,822 \\
\hline Boscalid $^{\text {a }}$ & 249 & $30-40$ & 9 & 2,195 & 1 & 2,052 \\
\hline Iprodione $^{\mathrm{b}}$ & 504 & $10-20$ & 16 & 1,872 & 4 & 1,968 \\
\hline Iprodione $^{\mathrm{b}}$ & 504 & $30-40$ & 19 & 2,058 & 2 & 2,008 \\
\hline Iprodione $^{\mathrm{b}}$ & 504 & $50-60$ & 7 & 2,199 & 1 & 2,019 \\
\hline Tebuconazole & 126 & $10-20$ & 32 & 1,896 & 8 & 1,861 \\
\hline Tebuconazole & 126 & $30-40$ & 41 & 1,634 & 14 & 2,103 \\
\hline Tebuconazole & 126 & $50-60$ & 19 & 2,014 & 3 & 2,055 \\
\hline Tebuconazole & 190 & $30-40$ & 25 & 1,994 & 8 & 2,019 \\
\hline Thiophanate-methyl & 785 & $30-40$ & 6 & 2,239 & 0 & 2,019 \\
\hline Vinclozolin & 420 & $10-20$ & 19 & 1,707 & 11 & 1,931 \\
\hline Vinclozolin & 420 & $30-40$ & 12 & 2,151 & 5 & 1,982 \\
\hline Vinclozolin & 420 & $50-60$ & 11 & 2,136 & 1 & 2,063 \\
\hline Vinclozolin & 375 & $30-40$ & 20 & 2,126 & 7 & 1,825 \\
\hline Vinclozolin ${ }^{\mathrm{a}}$ & 420 & $30-40$ & 24 & 1,892 & 6 & 2,169 \\
\hline $\mathrm{LSD} 0.05^{\mathrm{c}}$ & $\ldots$ & $\ldots$ & 24 & 350 & 6 & NS \\
\hline
\end{tabular}

a Included the adjuvant LOL 9831 at $1.25 \%$ (vol/vol).

${ }^{\mathrm{b}}$ Included the adjuvant Aphoil at $1 \%$ (vol/vol).

c Fisher's least significant difference, where $\alpha=0.05$. NS $=$ not statistically significant $(P \leq 0.05)$ according to the $F$ test. 
The fungicide treatments azoxystrobin without an adjuvant, boscalid applied at 30 to $50 \%$ bloom, iprodione, tebuconazole at $190 \mathrm{~g}$ a.i./ha, and vinclozolin at $420 \mathrm{~g}$ a.i./ha applied at 30 to $50 \%$ bloom with an adjuvant provided significant yield increases over the untreated control.

2001. Significant differences among fungicide treatments were detected for SSR incidence and yield at the Langdon REC in 2001 (Table 3). All fungicide treatments except azoxystrobin and tebuconazole at $126 \mathrm{~g}$ a.i./ha applied at 30 to $40 \%$ bloom significantly reduced SSR incidence compared with the untreated control. All fungicide treatments except azoxystrobin, tebuconazole at $126 \mathrm{~g}$ a.i./ha applied at 30 to $40 \%$ bloom, and vinclozolin at $420 \mathrm{~g}$ a.i./ha applied at 10 to $20 \%$ bloom provided significant yield increases over the untreated control.
Significant differences among fungicide treatments were detected for SSR incidence but not for yield at the commercial field in Langdon in 2001 (Table 3). All fungicide treatments had significantly lower SSR incidence than the untreated control, except azoxystrobin, tebuconazole at $126 \mathrm{~g}$ a.i./ha applied at 30 to $40 \%$ bloom, tebuconazole at $190 \mathrm{~g}$ a.i./ha applied at 30 to $40 \%$ bloom, vinclozolin at $420 \mathrm{~g}$ a.i./ha applied at 10 to $20 \%$ bloom, and vinclozolin at $375 \mathrm{~g}$ a.i./ha applied at 30 to $40 \%$ bloom.

Significant differences among fungicide treatments were detected for SSR incidence but not for yield at the Carrington REC in 2001 (Table 4). Fungicide treatments that significantly reduced SSR incidence compared with the untreated control were benomyl, boscalid at $200 \mathrm{~g}$ a.i./ha applied at 30 to $40 \%$ bloom, boscalid at

Table 4. Effect of fungicides on Sclerotinia stem rot (SSR) incidence and canola yield at Carrington, ND in 2001

\begin{tabular}{|c|c|c|c|c|}
\hline Fungicide & Rate (g a.i./ha) & Timing (\% bloom) & SSR incidence (\%) & Yield (kg/ha) \\
\hline Untreated & $\ldots$ & & 73 & 1,954 \\
\hline Azoxystrobin & 175 & $10-20$ & 63 & 1,627 \\
\hline Benomyl & 561 & $30-40$ & 35 & 2,259 \\
\hline Boscalid & 200 & $30-40$ & 43 & 2,086 \\
\hline Boscalid & 249 & $10-20$ & 58 & 1,898 \\
\hline Boscalid & 249 & $30-40$ & 46 & 2,281 \\
\hline Boscalid & 249 & $50-60$ & 62 & 2,059 \\
\hline Boscalid & 294 & $30-40$ & 39 & 2,132 \\
\hline Iprodione $^{\mathrm{a}}$ & 504 & $30-40$ & 12 & 2,355 \\
\hline Iprodione $^{\mathrm{a}}$ & 504 & $50-60$ & 65 & 1,888 \\
\hline Tebuconazole & 126 & $10-20$ & 94 & 1,977 \\
\hline Tebuconazole & 126 & $30-40$ & 43 & 2,178 \\
\hline Tebuconazole & 126 & $50-60$ & 71 & 2,085 \\
\hline Tebuconazole & 190 & $30-40$ & 76 & 1,983 \\
\hline Thiophanate-methyl & 785 & $10-20$ & 67 & 1,953 \\
\hline Thiophanate-methyl & 785 & $30-40$ & 23 & 1,976 \\
\hline Thiophanate-methyl & 785 & $50-60$ & 35 & 2,253 \\
\hline Vinclozolin & 420 & $10-20$ & 65 & 1,912 \\
\hline Vinclozolin & 420 & $30-40$ & 79 & 2,281 \\
\hline Vinclozolin & 420 & $50-60$ & 65 & 1,995 \\
\hline Vinclozolin & 375 & $30-40$ & 57 & 2,164 \\
\hline LSD $0.05^{\mathrm{b}}$ & $\ldots$ & $\ldots$ & 29 & NS \\
\hline
\end{tabular}

$294 \mathrm{~g}$ a.i./ha applied at 30 to $40 \%$ bloom, iprodione applied at 30 to $40 \%$ bloom, tebuconazole at $126 \mathrm{~g}$ a.i./ha applied at 30 to $40 \%$ bloom, and thiophanate-methyl applied at either 30 to $40 \%$ or 50 to $60 \%$ bloom.

Significant differences among fungicide treatments were detected for SSR incidence and yield at both commercial fields in Newburg in 2001 (Table 5). At commercial field 1, all fungicide treatments significantly reduced SSR incidence compared with the untreated control; however, only boscalid, thiophanatemethyl, and vinclozolin at $420 \mathrm{~g}$ a.i./ha provided a significant yield increase over the untreated control. At commercial field 2, all fungicide treatments significantly reduced SSR incidence and increased yield compared with the untreated control, except vinclozolin at $375 \mathrm{~g}$ a.i./ha with an adjuvant, which did not provide a significant yield increase over the untreated control.

Significant differences among fungicide treatments were detected for SSR incidence and yield at Red Lake Falls in 2001 (Table 6). All fungicide treatments except thiophanate-methyl at $785 \mathrm{~g}$ a.i./ha significantly reduced SSR incidence and increased yield compared with the untreated control.

2002. Significant differences among fungicide treatments were detected for SSR incidence but not yield at the Langdon REC in 2002 (Table 7). Fungicide treatments that significantly reduced SSR incidence compared with the untreated control were boscalid at 249 and 284 g a.i./ha, iprodione applied at 50 to $60 \%$ bloom, prothioconazole at $200 \mathrm{~g}$ a.i./ha applied at 50 to $60 \%$ bloom, thiophanatemethyl at $785 \mathrm{~g}$ a.i./ha applied at 50 to $60 \%$ bloom, and vinclozolin applied at 50 to $60 \%$ bloom.

2003. Significant differences among fungicide treatments were detected for SSR incidence and yield at the Langdon REC in 2003 (Table 8). Fungicide treat-

Table 5. Effect of fungicides on Sclerotinia stem rot (SSR) incidence and canola yield on two commercial fields located in Newburg, ND in 2001 ${ }^{\mathrm{a}}$

\begin{tabular}{|c|c|c|c|c|c|}
\hline \multirow[b]{2}{*}{ Fungicide } & \multirow[b]{2}{*}{ Rate (g a.i./ha) } & \multicolumn{2}{|c|}{ Commercial field 1} & \multicolumn{2}{|c|}{ Commercial field 2} \\
\hline & & SSR incidence $(\%)$ & Yield (kg/ha) & SSR incidence (\%) & Yield (kg/ha) \\
\hline Untreated & $\ldots$ & 34 & 1,868 & 39 & 2,254 \\
\hline Boscalid & 249 & 10 & 2,075 & 4 & 2,858 \\
\hline Iprodione $^{\mathrm{b}}$ & 504 & 13 & 1,979 & NI & NI \\
\hline Tebuconazole & 126 & 14 & 2,021 & NI & NI \\
\hline Tebuconazole ${ }^{c}$ & 126 & NI & NI & 19 & 2,687 \\
\hline Thiophanate-methyl & 785 & 8 & 2,229 & 3 & 2,768 \\
\hline Vinclozolin & 420 & 9 & 2,102 & 8 & 2,896 \\
\hline Vinclozolin & 375 & 14 & 2,052 & 10 & 2,742 \\
\hline Vinclozolin ${ }^{\mathrm{d}}$ & 420 & $\mathrm{NI}$ & NI & 8 & 2,692 \\
\hline Vinclozolin $^{\mathrm{d}}$ & 375 & NI & NI & 8 & 2,496 \\
\hline LSD $0.05^{\mathrm{e}}$ & $\ldots$ & 10 & 190 & 6 & 277 \\
\hline
\end{tabular}

${ }^{\text {a }}$ Fungicides were applied at 20 to $30 \%$ bloom in field 1 and at $40 \%$ bloom in field $2 ; \mathrm{NI}=$ treatment was not included in this trial.

${ }^{\mathrm{b}}$ Included the adjuvant Aphoil at $1 \%$ (vol/vol).

${ }^{c}$ Included the adjuvant Induce at $0.125 \%$ ( $\left.\mathrm{vol} / \mathrm{vol}\right)$.

${ }^{\mathrm{d}}$ Included a silicone adjuvant at $0.25 \%$ ( $\mathrm{vol} / \mathrm{vol}$ ).

e Fisher's least significant difference, where $\alpha=0.05$. 
ments that significantly reduced SSR incidence compared with the untreated control were boscalid applied at either 30 to $40 \%$ or 50 to $60 \%$ bloom and prothioconazole at either 175 or $200 \mathrm{~g}$ a.i./ha applied at 30 to $40 \%$ bloom. Fungicide treatments that provided a significant yield increase over the untreated control were boscalid applied
Table 6. Effect of fungicides on Sclerotinia stem rot (SSR) incidence and canola yield at Red Lake Falls, MN in $2001^{\mathrm{a}}$

\begin{tabular}{lccc}
\hline Fungicide & Rate (g a.i./ha) & SSR incidence (\%) & Yield (kg/ha) \\
\hline Untreated & $\ldots$ & 61 & 1,403 \\
Benomyl & 561 & 9 & 1,715 \\
Thiophanate-methyl & 1,176 & 23 & 1,742 \\
Thiophanate-methyl & 785 & 48 & 1,586 \\
Vinclozolin & 420 & 35 & 1,673 \\
LSD 0.05 & $\ldots$ & 17 & 234 \\
\hline
\end{tabular}

${ }^{a}$ Fungicides were applied at $30 \%$ bloom.

${ }^{\mathrm{b}}$ Fisher's least significant difference, where $\alpha=0.05$.

Table 7. Effect of fungicides on Sclerotinia stem rot (SSR) incidence and canola yield at Langdon, ND in 2002

\begin{tabular}{|c|c|c|c|c|}
\hline Fungicide & Rate (g a.i./ha) & Timing (\% bloom) & SSR incidence (\%) & Yield (kg/ha) \\
\hline Untreated & $\ldots$ & & 51 & 2,107 \\
\hline Boscalid & 249 & $30-40$ & 20 & 2,550 \\
\hline Boscalid & 284 & $50-60$ & 9 & 2,575 \\
\hline Iprodione $^{\mathrm{a}}$ & 504 & $30-40$ & 39 & 2,221 \\
\hline Iprodione $^{\mathrm{a}}$ & 504 & $50-60$ & 25 & 2,388 \\
\hline Iprodione $^{\mathrm{b}}$ & 504 & $30-40$ & 40 & 2,410 \\
\hline Prothioconazole ${ }^{c}$ & 151 & $30-40$ & 37 & 2,217 \\
\hline Prothioconazole ${ }^{c}$ & 151 & $50-60$ & 34 & 2,407 \\
\hline Prothioconazole ${ }^{c}$ & 200 & $30-40$ & 35 & 2,341 \\
\hline Prothioconazole ${ }^{c}$ & 200 & $50-60$ & 21 & 2,615 \\
\hline Thiophanate-methyl & 785 & $30-40$ & 39 & 2,206 \\
\hline Thiophanate-methyl & 785 & $50-60$ & 19 & 2,583 \\
\hline Thiophanate-methyl & 1,175 & $30-40$ & 46 & 2,429 \\
\hline Thiophanate-methyl $^{\mathrm{b}}$ & 785 & $30-40$ & 31 & 2,429 \\
\hline Vinclozolin & 420 & $30-40$ & 49 & 2,180 \\
\hline Vinclozolin & 420 & $50-60$ & 24 & 2,440 \\
\hline LSD $0.05^{\mathrm{d}}$ & $\ldots$ & $\ldots$ & 22 & NS \\
\hline $\begin{array}{l}\text { a Included the adjuva } \\
\text { b Included the adjuva } \\
\text { c Included the adjuva } \\
\text { d Fisher's least signi }\end{array}$ & $\begin{array}{l}\text { Aphoil at } 1 \%(\mathrm{vo} \\
\text { Prime Oil at } 1 \% \\
\text { Induce at } 1.25 \% \\
\text { ant difference, }\end{array}$ & $\begin{array}{l}\text { ol). } \\
\text { ol/vol). } \\
\text { ol/vol). } \\
\text { ere } \alpha=0.05 . \mathrm{NS}=\end{array}$ & not statistically sign & cant $(P \leq 0.05)$ \\
\hline
\end{tabular}

at either 30 to 40 or 50 to $60 \%$ bloom, iprodione applied at either 30 to $40 \%$ or 50 to $60 \%$ bloom, prothioconazole at either 175 or $200 \mathrm{~g}$ a.i./ha applied at either 30 to $40 \%$ or 50 to $60 \%$ bloom, V-10116 applied at 30 to $40 \%$ bloom, and vinclozolin applied at 50 to $60 \%$ bloom.

Significant differences among fungicide treatments were detected for SSR incidence but not yield at the Carrington REC in 2003 (Table 8). Fungicide treatments that significantly reduced SSR incidence compared with the untreated control were boscalid applied at 50 to $60 \%$ bloom and prothioconazole at either 175 or $200 \mathrm{~g}$ a.i./ha applied at 50 to $60 \%$ bloom.

Significant differences among fungicide treatments were detected for SSR incidence but not yield at the Minot REC in 2003 (Table 8). All fungicide treatments significantly reduced SSR incidence compared with the untreated control, except PCNB applied at 30 to $40 \%$ bloom and V10116 applied at 30 to $40 \%$ bloom.

Significant differences among fungicide treatments were detected for SSR incidence but not yield at Red Lake Falls in 2003 (Table 8). All fungicide treatments significantly reduced SSR incidence compared with the untreated control.

2004. Significant differences among fungicide treatments were detected for SSR incidence but not yield at the Langdon REC in 2004 (Table 9). No significant differences were detected among fungicide treatments for either SSR incidence or yield at the Carrington REC and Red Lake Falls in 2004. At the Langdon REC, all fungicide treatments significantly reduced SSR incidence compared with the untreated control.

Table 8. Effect of fungicides on Sclerotinia stem rot (SSR) incidence and canola yield at Langdon, Carrington, and Minot, ND and Red Lake Falls, MN in 2003

\begin{tabular}{|c|c|c|c|c|c|c|c|c|c|c|}
\hline \multirow[b]{2}{*}{ Fungicide } & \multirow[b]{2}{*}{$\begin{array}{c}\text { Rate } \\
\text { (g a.i./ha) }\end{array}$} & \multirow[b]{2}{*}{$\begin{array}{c}\text { Bloom } \\
(\%)\end{array}$} & \multicolumn{2}{|c|}{ Langdon } & \multicolumn{2}{|c|}{ Carrington } & \multicolumn{2}{|c|}{ Minot } & \multicolumn{2}{|c|}{ Red Lake Falls } \\
\hline & & & $\begin{array}{c}\text { SSR } \\
(\%)\end{array}$ & $\begin{array}{c}\text { Yield } \\
\text { (kg/ha) }\end{array}$ & $\begin{array}{l}\text { SSR } \\
(\%)\end{array}$ & $\begin{array}{c}\text { Yield } \\
\text { (kg/ha) }\end{array}$ & $\begin{array}{l}\text { SSR } \\
(\%)\end{array}$ & $\begin{array}{c}\text { Yield } \\
\text { (kg/ha) }\end{array}$ & $\begin{array}{c}\text { SSR } \\
(\%)\end{array}$ & $\begin{array}{c}\text { Yield } \\
\text { (kg/ha) }\end{array}$ \\
\hline Untreated & & & 89 & 1,668 & 69 & 1,687 & 8 & 2,936 & 25 & 1,970 \\
\hline Boscalid & 284 & $30-40$ & 65 & 2,176 & 58 & 1,752 & 1 & 2,893 & 9 & 1,925 \\
\hline Boscalid & 284 & $50-60$ & 66 & 2,410 & 44 & 1,865 & 1 & 3,119 & 5 & 2,006 \\
\hline Iprodione $^{\mathrm{b}}$ & 504 & $30-40$ & 77 & 2,286 & 64 & 1,694 & 5 & 3,167 & 5 & 1,866 \\
\hline Iprodione $^{\mathrm{b}}$ & 504 & $50-60$ & 92 & 2,446 & 57 & 1,613 & 3 & 2,732 & 5 & 2,002 \\
\hline PCNB & 1,680 & $30-40$ & 99 & 1,785 & 59 & 1,530 & 8 & 2,968 & 12 & 1,905 \\
\hline $\mathrm{PCNB}$ & 1,680 & $50-60$ & NI & NI & 63 & 1,636 & NI & NI & NI & NI \\
\hline $\mathrm{PCNB}+$ thiophanate-methyl & $1,680+393$ & $30-40$ & 98 & 1,844 & 63 & 1,563 & 4 & 2,979 & 15 & 1,943 \\
\hline Prothioconazole $^{c}$ & 175 & $30-40$ & 50 & 2,520 & 55 & 1,920 & 3 & 3,292 & 5 & 1,998 \\
\hline Prothioconazole ${ }^{c}$ & 175 & $50-60$ & 73 & 2,688 & 49 & 1,928 & 2 & 2,732 & 5 & 2,065 \\
\hline Prothioconazole ${ }^{c}$ & 200 & $30-40$ & 54 & 2,366 & 57 & 1,892 & 1 & 2,954 & 7 & 2,010 \\
\hline Prothioconazole ${ }^{c}$ & 200 & $50-60$ & 79 & 2,681 & 47 & 1,826 & 2 & 3,188 & 4 & 2,060 \\
\hline Thiophanate-methyl & 393 & $30-40$ & 93 & 2,048 & $\mathrm{NI}$ & NI & 3 & 3,308 & 5 & 1,663 \\
\hline Thiophanate-methyl & 785 & $30-40$ & 94 & 2,102 & 75 & 1,739 & 2 & 3,238 & 5 & 1,923 \\
\hline Thiophanate-methyl & 785 & $50-60$ & 81 & 1,877 & 65 & 1,680 & 2 & 3,218 & 5 & 1,848 \\
\hline V-10116 & 141 & $30-40$ & 93 & 2,231 & 59 & 1,932 & 6 & 3,480 & - & - \\
\hline V-10116 & 141 & $50-60$ & 89 & 1,957 & 58 & 1,955 & 4 & 3,018 & 12 & 2,068 \\
\hline Vinclozolin & 420 & $30-40$ & 83 & 2,147 & 77 & 1,734 & 2 & 3,134 & 9 & 1,931 \\
\hline Vinclozolin & 420 & $50-60$ & 72 & 2,289 & 66 & 1,830 & 2 & 3,237 & 7 & 1,888 \\
\hline LSD $0.05^{\mathrm{d}}$ & $\ldots$ & $\ldots$ & 23 & 495 & 15 & NS & 3 & NS & 7 & NS \\
\hline
\end{tabular}

a $\mathrm{PCNB}=$ pentachloronitrobenzene and $\mathrm{NI}=$ treatment was not included in this trial.

b Included either crop oil concentrate or Aphoil as an adjuvant at $1 \%$ (vol/vol).

c Included the adjuvant Induce at $0.125 \%$ (vol/vol).

d Fisher's least significant difference, where $\alpha=0.05$. NS $=$ not statistically significant $(P \leq 0.05)$ according to the $F$ test. 


\section{DISCUSSION}

Fungicide active ingredients currently registered in the United States for control of SSR on canola are azoxystrobin, boscalid, thiophanate-methyl, and vinclozolin, in which each represents a distinct chemical group: quinone outside inhibitors (QoI), carboxamides, methyl benzimidazole carbamates (MBC), and dicarboximides, respectively. When applied at labeled rates, all of these fungicides significantly reduced SSR incidence compared with the untreated control on a consistent basis. The reductions in SSR incidence sometimes resulted in a significant increase in yield over the untreated control as well. Vinclozolin previously was reported to control SSR effectively in rapeseed (2). Fungicide recommendations to canola growers should include rotation among the registered active ingredients to slow down the selection for fungicideresistant isolates. Although fungicideresistant populations of $S$. sclerotiorum have not yet been observed in North Dakota, S. sclerotiorum isolates resistant to MBC fungicides have been reported in Canada and China (3,15). Mueller et al. (8) reported that several isolates of S. sclerotiorum from Illinois and other states had reduced sensitivity to thiophanate-methyl, thus showing that the potential of developing resistance to this $\mathrm{MBC}$ fungicide could be realized. Even though $S$. sclerotiorum populations resistant to QoI, carboxamide, and dicarboximide fungicide groups have not been identified thus far, resistance management practices still should be recommended because the fungicide chemical groups registered on canola for SSR control in the United States are classified as either medium risk, medium to high risk, or high risk by the Fungicide Resistance Action Committee.

In addition to the fungicide active ingredients currently registered on canola, some of the nonregistered fungicides provided significantly better SSR control than the untreated control on a relatively consistent basis. These fungicides included iprodione, prothioconazole, tebuconazole, and trifloxystrobin. Iprodione previously has been reported to provide control of SSR on rapeseed in Canada $(2,11)$. Tebuconazole was reported to reduce SSR severity on soybean (Glycine max) in the greenhouse (8), but its efficacy against SSR on canola in the field does not appear to have been reported previously. Trifloxystrobin did not improve marketable yield of snap bean (Phaseolus vulgaris) over an untreated control under white mold (S. sclerotiorum) pressure in New York (10). Conversely, trifloxystrobin did significantly reduce SSR incidence in our canola trials, although it was tested in 1 year only. If registered on canola in the United States, these fungicide active ingredients would provide canola growers with more products to choose from which could help drive down the price, making fungicides more economical to apply. Prothioconazole and tebuconazole both belong to the demethylation inhibitors fungicide group. If registered, this would give canola growers one more fungicide group to rotate with that would help with fungicide resistance management.

Different application timings of the fungicides were evaluated in some of the trials, which ranged from 10 to $60 \%$ bloom. Dueck et al. (2) reported that effective control of SSR was achieved when fungicides were applied at $25 \%$ bloom, and Thomson et al. (11) reported effective control of SSR when fungicides were applied at 20 to $30 \%$ or 30 to $50 \%$ bloom. In our trials, one specific timing did not necessarily result in the best control for all of the locations and years. The application timing did not appear to make a difference in some years and locations, but in others it did. A specific percent bloom timing may not be the best guide to use to determine when to apply a fungicide for SSR control in canola. Although senescing canola petals need to be present for $S$. sclerotiorum ascospores to infect (9), other factors such as weather and apothecia development also need to be considered for the best time to apply a fungicide. Using disease forecasting such as the Sclerotinia risk forecasting system (6), which predicts the development of apothecia, or measuring petal infestation (12-14) may provide guidance in determining when to apply a fungicide.

Because fungicides are an added expense, the return on the investment of a fungicide is a major consideration when a canola grower is making a decision whether to spray or not. The four fungicides currently registered for control of SSR in canola are priced quite differently. The current approximate price for each fungicide is $\$ 0.30 / \mathrm{g}$ a.i. azoxystrobin (Quadris; registered rate $=113$ to 281 g a.i./ha), \$0.28/g a.i. boscalid (Endura; registered rate $=245$ to $294 \mathrm{~g}$ a.i./ha), $\$ 0.06 / g$ a.i. thiophanate-methyl (Topsin M; registered rate $=785$ to $1,570 \mathrm{~g}$ a.i./ha), and $\$ 0.10 / \mathrm{g}$ a.i. vinclozolin (Ronilan; registered rate $=372$ to $560 \mathrm{~g}$ a.i./ha. The 10 year average canola marketing price for North Dakota growers is $\$ 0.22 / \mathrm{kg}$ (1995 to 2004; National Agriculture Statistics Service). Based on these prices and our results, a grower would have at least a "break-even" return on each fungicide the following number of times (based on the number of times evaluated at registered rates in our trials): $43 \%$ of the time (3 of 7 times) for azoxystrobin, $41 \%$ of the time (13 of 32 times) for boscalid, $44 \%$ of the time (12 of 27 times) for thiophanatemethyl, and $60 \%$ of the time (26 of 43 times) for vinclozolin. To stay profitable, canola growers should observe yield potential, disease and weather forecasting systems, and price and efficacy of fungicides before making the decision to spray their canola fields to control SSR.

From the results presented herein, fungicides can be used effectively to control SSR and minimize yield reductions in canola. Fungicides currently registered in the United States for SSR control on canola are effective if applied at labeled rates; however, caution should be taken to rotate among the fungicide groups to slow down the selection for fungicide-resistant isolates. Some of the fungicides not currently registered for application on canola in the United States were efficacious against SSR and would provide canola growers with more management options if they become registered for use on canola in the United States. Although fungicides are effective in reducing SSR incidence, yield reductions still do occur often, especially under heavy disease pressure. More research is needed in evaluating fungicide application technologies for SSR control in

Table 9. Effect of fungicides on Sclerotinia stem rot (SSR) incidence and canola yield at Langdon and Carrington, ND and Red Lake Falls, MN in 2004

\begin{tabular}{|c|c|c|c|c|c|c|c|c|}
\hline \multirow[b]{2}{*}{ Fungicide } & \multirow[b]{2}{*}{ Rate (g. a.i./ha) } & \multirow[b]{2}{*}{ Bloom (\%) } & \multicolumn{2}{|c|}{ Langdon } & \multicolumn{2}{|c|}{ Carrington } & \multicolumn{2}{|c|}{ Red Lake Falls } \\
\hline & & & $\operatorname{SSR}(\%)$ & Yield (kg/ha) & $\operatorname{SSR}(\%)$ & Yield (kg/ha) & $\operatorname{SSR}(\%)$ & Yield (kg/ha) \\
\hline Untreated & $\ldots$ & $\ldots$ & 95 & 1,889 & 5 & 2,870 & 4 & 2,643 \\
\hline Boscalid & 269 & $30-40$ & 27 & 2,382 & 3 & 2,969 & 0 & 2,860 \\
\hline Prothioconazole $^{\mathrm{a}}$ & 151 & $50-60$ & 50 & 2,303 & 2 & 2,723 & 1 & 2,636 \\
\hline Prothioconazole $^{\mathrm{a}}$ & 175 & $50-60$ & 32 & 2,576 & 1 & 3,066 & 1 & 2,602 \\
\hline Thiophanate-methyl & 785 & $30-40$ & 66 & 2,190 & 3 & 2,862 & 4 & 2,734 \\
\hline Thiophanate-methyl & 785 & $50-60$ & 50 & 2,366 & 3 & 2,763 & 1 & 2,607 \\
\hline V-10116 & 134 & $30-40$ & 63 & 2,472 & 3 & 3,291 & 1 & 2,924 \\
\hline Vinclozolin & 420 & $30-40$ & 63 & 2,112 & 3 & 2,896 & 6 & 2,793 \\
\hline LSD $0.05^{\mathrm{b}}$ & $\ldots$ & $\ldots$ & 27 & NS & NS & NS & NS & NS \\
\hline
\end{tabular}

${ }^{a}$ Included the adjuvant Induce at $0.125 \%$ (vol/vol).

b Fisher's least significant difference, where $\alpha=0.05$. NS $=$ not statistically significant $(P \leq 0.05)$ according to the $F$ test. 
canola. Newer application technology may allow for better fungicide coverage, which could result in better control.

\section{ACKNOWLEDGMENTS}

This research was supported by the United States Department of Agriculture CSREES National and North Central Canola Research Programs, the Northern Canola Growers Association, and the Minnesota Canola Council.

\section{LITERATURE CITED}

1. Bradley, C. A., Henson, R. A., Porter, P. M., LeGare, D. G., del Río, L. E., and Khot. S. D. 2006. Response of canola cultivars to Sclerotinia sclerotiorum in controlled and field environments. Plant Dis. 90:215-219.

2. Dueck, J., Morrall, R. A. A., and McKenzie, D. L. 1983. Control of Sclerotinia sclerotiorum in rapeseed with fungicides. Can. J. Plant Pathol. 5:289-293

3. Gossen, B. D., Rimmer, S. R., and Holley, J. D. 2001. First report of resistance to benomyl fungicide in Sclerotinia sclerotiorum. Plant Dis. 85:1206.

4. Lamey, A., Knodel, J., Endres, G., Andol, K., Ashley, R., Beneda, R., Johnson, N., Knoke, S., Liane, M., Lykken, T., Miller, M.,
Nyegaard, C., and Peterson, N. 2002. 2002 Canola disease survey in Minnesota and North Dakota. N. D. State Univ. Ext. Rep. No. 80.

5. Lamey, H. A. 1995. Blackleg and Sclerotinia disease of canola in North Dakota in 1991 and 1993. Plant Dis. 79:322-324.

6. McLaren, D. L., Conner, R. L., Platford, R. G., Lamb, J. L., Lamey, H. A., and Kutcher, H. R. 2004. Predicting diseases caused by Sclerotinia sclerotiorum on canola and bean-a western Canadian perspective. Can. J. Plant Pathol. 26:489-497.

7. McMullen, M. P., and Bradley, C. A. 2005. 2005 North Dakota field crop fungicide guide. N. D. State Univ. Ext. Rep. No. PP-622.

8. Mueller, D. S., Dorrance, A. E., Derksen, R. C., Ozkan, E., Kurle, J. E., Grau, C. R., Gaska, J. M., Hartman, G. L., Bradley, C. A., and Pedersen, W. L. 2002. Efficacy of fungicides on Sclerotinia sclerotiorum and their potential for control of Sclerotinia stem rot on soybean. Plant Dis. 86:26-31.

9. Rimmer, S. R., Kutcher, H. R., and Morrall, R. A. A. 2003. Diseases of canola and mustard. Pages 129-146 in: Diseases of Field Crops in Canada, 3rd ed. K. L. Bailey, B. D. Gossen, R. K. Gugel, and R. A. A. Morrall, eds. University Extension Press, Saskatoon, SK, Canada.

10. Shah, D. A., Dillard, H. R., and Cobb, A. C.
2002. Alternatives to vinclozolin (Ronilan) for controlling gray and white mold on snap bean pods in New York. Online. Plant Health Progress doi:10.1094/PHP-2002-0923-01-RS.

11. Thomson, J. R., Thomas, P. M., and Evans, I. R. 1984. Efficacy of aerial application of benomyl and iprodione for the control of Sclerotinia stem rot of canola (rapeseed) in central Alberta. Can. J. Plant Pathol. 6:75-77.

12. Turkington, T. K., and Morrall, R. A. A. 1993 Use of petal infestation to forecast Sclerotinia stem rot of canola: the influence of inoculum variation over the flowering period and canopy density. Phytopathology 83:682-689.

13. Turkington, T. K., Morrall, R. A. A., and Gugel, R. K. 1991. Use of petal infestation to forecast Sclerotinia stem rot of canola: Evaluation of early bloom sampling, 1985-90. Can. J. Plant Pathol. 13:50-59.

14. Turkington, T. K., Morrall, R. A. A., and Rude, S. V. 1991. Use of petal infestation to forecast Sclerotinia stem rot of canola: the impact of diurnal and weather-related inoculum fluctuations. Can. J. Plant Pathol. 13:347-355.

15. Zhiqi, S., Mingguo, Z., Zhongyin, Y., Jianrong, S., Huaigu, C., and Yuzhong, W. 2000. Resistance monitoring of Sclerotinia sclerotiorum to carbendazim. Jiangsu J. Agric. Sci. 16:226229. 